ANDRZEJ RACZYK

Uniwersytet Wrocławski

Helena Dobrowolska-Kaniewska

Dolnośląska Agencja Współpracy Gospodarczej, Wrocław

\title{
Ksztaltowanie struktur przestrzennych sektora przemysłu i usług według poziomów techniki na przykładzie województwa dolnośląskiego
}

Współczesne procesy społeczno-gospodarcze wymuszają wzrost znaczenia dziedzin, które w dużej mierze opierają się na intensywnym wykorzystaniu wiedzy. Do dziedzin tych zalicza się przede wszystkim podmioty gospodarcze sektora produkcji i usług wysokiej techniki, wysokiej technologii, high-tech, charakteryzujące się obok wysokiego poziomu wydatków na działalność $\mathrm{B}+\mathrm{R}$, także wysokim poziomem innowacyjności, krótkim cyklem życiowym wyprodukowanych wyrobów oraz tworzonych procesów czy świadczonych usług, a więc szybkimi procesami dyfuzji innowacji. Ponadto przedsiębiorstwa te posiadają znaczny udział pracujących należących do tzw. personelu naukowo-badawczego oraz pracowników o wysokich kwalifikacjach. Rozwijają strategiczną współpracę z innymi firmami wysokotechnologicznymi oraz krajowymi i zagranicznymi instytucjami badawczymi. Uważa się także, że podmioty należące do wysokiej techniki ponoszą znaczne nakłady kapitałowe i ryzyko inwestycyjne w związku z szybkim „starzeniem” się inwestycji (Informacja o stanie... 2003, s. 5).

Szczególną rolę w powstawaniu podmiotów gospodarczych, w tym zaliczanych do sektora wysokiej techniki, odgrywają miasta, które stanowią miejsca koncentracji działalności społeczno-ekonomicznej i są podstawą tworzenia Regionalnych Systemów Innowacyjnych opartych na sieci współpracy.

Oprócz przemysłu bardzo istotną rolę w rozwoju gospodarczym odgrywa sektor usług, w tym przede wszystkim usług wyspecjalizowanych, które charakteryzują się wzrastającą rolą specjalistów oraz naukowców w strukturze zatrudnienia. Należy przy tym podkreślić, iż poza bezpośrednim wpływem na poziom wykorzystania poszczególnych technologii kształtują one ogólne warunki funkcjonowania podmiotów gospodarczych, w tym również jednostek przemysłowych.

Prowadzone dotychczas w literaturze krajowej badania przemysłu i usług według poziomu techniki skupiają się przede wszystkim na analizach poszczególnych sektorów w strukturze gospodarki, wielkości produkcji sprzedanej wyrobów nowych lub zmodernizowanych, nakładów na $\mathrm{B}+\mathrm{R}$ w poszczególnych sektorach oraz udziału pracujących. Analizy przestrzenne najczęściej odnoszą się przy tym do poziomu krajowego lub regionalnego-po- 
ziom NTS 2 (por. Wojnicka, Piekarec, Rot 2000; Niedzielski 2003; Fic 2004; Kozioł 2004; Janasz 2005, Chojnicki, Czyż 2006). Relatywnie niewiele opracowań poświęcono problematyce kształtowania się zróżnicowań przestrzennych w układach lokalnych, które pozwoliłyby określić rzeczywiste uwarunkowania powstawania takich podmiotów. W szczególności dotyczy to analizy sektora usług.

Celem opracowania było zbadanie kształtowania się zróżnicowań przestrzennych zmian liczby i struktury podmiotów gospodarczych oraz pracujących w obrębie działów sektora przemysłu i usług według poziomu rozwoju technologicznego (zgodnie z klasyfikacją stosowaną przez OECD). Ponadto dokonano analizy uwarunkowań powstawania podmiotów gospodarczych o wysokim, średnim oraz niskim poziomie techniki oraz intensywności badań i rozwoju. Zbadano również wzajemne relacje przestrzenne między występowaniem jednostek poszczególnych grup technologicznych a poziomem rozwoju sektora usług, przedsiębiorczości oraz kapitału ludzkiego.

Badanie przeprowadzono w odniesieniu do gmin (poziom LAU 2) województwa dolnośląskiego w 1998 oraz 2004 roku. Dane statystyczne o podmiotach gospodarczych pozyskano z rejestru REGON prowadzonego przez Wojewódzki Urząd Statystyczny we Wrocławiu. W pracy podmioty sekcji przetwórstwa przemysłowego średnioniskiej oraz średniowysokiej techniki analizowano łącznie stosując dla nich określenie średniej techniki. Ponadto poszczególne grupy podmiotów według poziomów techniki oraz pracujących według intensywności badań i rozwoju w celu ułatwienia wzajemnych porównań oraz zachowania jednolitej terminologii określono jako kategorie (por. tab. 1, 2).

\section{METODY KLASYFIKACJI PODMIOTÓW ZE WZGLĘDU NA POZIOM TECHNIKI -} SEKTOR PRZEMYSŁU I USŁUG

Pojęcie „przemysłu wysokich technologii” pojawiło się w połowie lat sześćdziesiątych $\mathrm{XX}$ wieku. Rozwój podmiotów przemysłowych zaliczanych do wysokiej techniki stanowi jeden z głównych czynników wpływających na wzrost i rozwój gospodarczy oraz konkurencyjność gospodarki w wymiarze krajowym i regionalnym. Dzieje się tak dlatego, że działalność tego sektora na styku nauki i przemysłu przekłada się na adaptowanie osiagnięć naukowych do gospodarki, tworzenie nowej wiedzy, zatrudnianie wykształconego i kreatywnego personelu i przyczynia się do (Fic 2004):

- wzrostu konkurencji technologicznej pomiędzy przedsiębiorstwami oraz ciągłego doskonalenia parametrów jakościowych wyrobów i usług,

- wzrostu efektów użytkowych produktów, mierzonego parametrami techniczno-ekonomicznymi,

- postępu technicznego, który ulega rozprzestrzenianiu w miarę wzrostu ilościowego sektora wysokich technologii, ponieważ prowadzenie produkcji dóbr i usług high-tech zachęca do wprowadzania na rynek nowych, zaawansowanych technologicznie wyrobów,

- postępu technologicznego w przemysłach zaliczanych do sektora średniej i niskiej techniki,

- wzrostu popytu na produkty tego sektora, co przekłada się na wzrost popytu na dobra dodatkowe i powstawanie nowych potrzeb konsumpcyjnych,

- spadku importu produktów high-tech. 
Oprócz przemysłu wysokiej techniki bardzo istotne w rozwoju gospodarczym są usługi, przede wszystkim usługi wyspecjalizowane, które charakteryzują się rosnącą rolą specjalistów oraz naukowców w strukturze zatrudnienia. Należy przy tym podkreślić, iż poza bezpośrednim wpływem na poziom wykorzystania poszczególnych technologii, kształtują one ogólne warunki prowadzenia działalności gospodarczej, w tym dla podmiotów przemysłowych.

W literaturze spotyka się dwa kryteria zaliczania poszczególnych działów gospodarki do przemysłów wysokiej techniki (Karpiński 1998):

1. Intensywność prac naukowo-badawczych, mierzoną odsetkiem pracowników naukowo-badawczych pracujących w zapleczu B+R do ogółu zatrudnienia w przemyśle;

2. Odsetek wydatków na działalność badawczo-rozwojową, nazywany wskaźnikiem intensywności B+R. Może on być szacowany zarówno w odniesieniu do dziedzin przemysłu (metoda dziedzinowa), jak i poszczególnych wyrobów lub ich grup (metoda produktowa).

Wydzielenie sektora produkcji według poziomów techniki przeprowadzono na podstawie najnowszej listy dziedzin (działów) opublikowanej przez OECD w 1997 r. (tab. 1). Metoda ta charakteryzuje się wysokim stopniem agregacji danych. Wynika to z faktu, iż całość nakładów na działalność $\mathrm{B}+\mathrm{R}$ w danym sektorze techniki jest przypisana do podstawowego rodzaju działalności firm składających się na dany sektor. Powodować to może przeszacowanie intensywności technologicznej w jednych sektorach kosztem jej niedoszacowania w innych. Istotną wadą tej metody jest również to, iż wiele wyrobów produkowanych przez firmy zaliczane do wysokiej techniki w rzeczywistości reprezentuje średnią lub niską technikę i odwrotnie. Wady tej metody mogą być niwelowane drugą metodą, tzw. metodą podziału podmiotów gospodarczych według wyrobów (metoda produktowa), w ramach której określa się intensywność technologiczną wyrobów, a nie gałęzi czy przedsiębiorstw. Skonstruowana jest ona na podstawie szczegółowych danych dotyczących nakładów na działalność B+R według grupy wyrobów wysokiej techniki. W 1995 OECD opublikowało listę tych wyrobów, do której zaliczono (Definicje... 1999, s. 194): 1. sprzęt lotniczy, 2. komputery i maszyny biurowe, 3. sprzęt elektroniczny i telekomunikacyjny, 4. środki farmaceutyczne, 5. aparaturę naukowo-badawcza, 6. maszyny elektryczne, 7. maszyny nieelektryczne, 8. chemikalia, 9. uzbrojenie.

W grupie tych wyrobów wyodrębniono dwie dalsze kategorie, a mianowicie:

- ultrawysoką technikę, inaczej nazywaną techniką brzegową (leading-edge products),

- technikę wysokiego poziomu (high-level technology).

Pierwsza grupa obejmuje wyroby charakteryzujące się najwyższą intensywnością $B+R$, bardzo często wyroby zaliczane do tej kategorii ze względu na swoją rolę w rozwoju społeczno-ekonomicznym oraz obronnym kraju podlegają różnym formom protekcjonizmu i interwencjonizmu ze strony państwa (energia nuklearna, uzbrojenie itp.). Natomiast druga grupę stanowią produkty o bardziej masowej produkcji i konsumpcji podlegające prawom wolnego rynku (maszyny elektryczne i nieelektryczne, komputery itp.).

Także i ta metoda ma pewne słabości, przede wszystkim z powodu trudności przygotowania dostatecznie szczegółowej listy wyrobów oraz ustalenia hierarchii wyrobów, która odzwierciedlałaby ich techniczne i technologiczne specyfikacje (Kozioł 2004). W Polsce analizy dotyczące wyrobów wysokiej techniki odnoszą się do udziału eksportu i importu, produkcji sprzedanej wyrobów według poziomów techniki, a informacje te udostępniane są jedynie na poziomie kraju. Z uwagi na brak danych statystycznych w analizowanym układzie przestrzennym metoda ta nie mogła być wykorzystana w artykule. 
Do opisu podmiotów gospodarczych w obrębie sektora usług posłużono się w pracy klasyfikacją pracujących według poziomów intensywności $\mathrm{B}+\mathrm{R}$ (por. tab. 2).

Analiza aktywności sektorów high-tech metodą dziedzinową może być przeprowadzona na dwa sposoby. Po pierwsze, uwzględniając jedynie działy high-tech produkcji oraz usług i taka została zastosowana w pracy. Ponadto może obejmować działy high-tech sektora produkcji, przy czym składają się na nań zarówno działy wysokiej, jak i średniowysokiej techniki oraz działy zaliczane do pozostałych usług opartych na wiedzy łącznie z usługami high-tech (por. Chojnicki, Czyż 2006).

Z punktu widzenia kształtowania procesów rozwoju społeczno-ekonomicznego poszczególnych obszarów najważniejszą rolę odgrywają dwa zjawiska:

- powstawanie nowych i rozwój istniejących podmiotów gospodarczych,

- ,jakość" tych podmiotów, określana przynależnością do poszczególnych sektorów działalności produkcyjnej i usługowej według poziomów techniki.

W tym kontekście najlepszym do analizy wydaje się wskaźnik liczby podmiotów gospodarczych poszczególnych kategorii w odniesieniu do mieszkańców w wieku produkcyjnym (wskaźnik przedsiębiorczości). Wskaźnik ten wykorzystano w pracy. Wskaźnik strukturalny W analizach na poziomie lokalnym może być stosowany jedynie uzupełniająco. Wynika to z faktu, iż struktura firm nie zawsze oddaje rzeczywisty poziomu rozwoju techniki, ponieważ wysoki udział poszczególnych kategorii może być wynikiem ogólnie małej liczby jednostek (i odwrotnie).

Tab. 1. Klasyfikacja sekcji Przetwórstwo przemysłowe według poziomów techniki

\begin{tabular}{|c|l|}
\hline $\begin{array}{c}\text { Symbol działu } \\
\text { w PKD }\end{array}$ & \multicolumn{1}{c|}{ Wrazwa działu według PKD } \\
\hline \multicolumn{2}{|c|}{ WYKA TECHNIKA - I kategoria } \\
\hline 24.4 & Produkcja wyrobów farmaceutycznych \\
\hline 30 & Produkcja maszyn biurowych i komputerów \\
\hline 32 & Produkcja sprzętu i urządzeń radiowych telewizyjnych i telekomunikacyjnych \\
\hline 33 & $\begin{array}{l}\text { Produkcja instrumentów medycznych, precyzyjnych i optycznych, zegarów } \\
\text { i zegarków }\end{array}$ \\
\hline 35.3 & Produkcja statków powietrznych i kosmicznych \\
\hline 24 bez 24.4 & Produkcja wyrobów chemicznych, bez produkcji wyrobów farmaceutycznych \\
\hline 29 & Produkcja maszyn i urządzeń, gdzie indziej niesklasyfikowana \\
\hline 31 & Produkcja maszyn i aparatury elektrycznej, gdzie indziej niesklasyfikowana \\
\hline 34 & Produkcja pojazdów mechanicznych, przyczep i naczep \\
\hline $35.2+35.4+35.5$ & $\begin{array}{l}\text { Produkcja lokomotyw kolejowych i tramwajowych oraz taboru kolejowego } \\
\text { i tramwajowego, Produkcja motocykli i rowerów, Produkcja pozostałego } \\
\text { sprzętu transportowego, gdzie indziej niesklasyfikowana }\end{array}$ \\
\hline \multicolumn{2}{|c|}{ ŚREDNIONISKA TECHNIKA - II kategoria } \\
\hline 23 & Wytwarzanie koksu, produktów rafinacji ropy naftowej i paliw jądrowych \\
\hline 25 & Produkcja wyrobów gumowych i z tworzyw sztucznych \\
\hline &
\end{tabular}




\begin{tabular}{|c|l|}
\hline 26 & Produkcja wyrobów z surowców niemetalicznych pozostałych \\
\hline 27 & Produkcja metali \\
\hline 28 & Produkcja metalowych wyrobów gotowych, z wyjątkiem maszyn i urządzeń \\
\hline 35.1 & Produkcja i naprawa statków i łodzi \\
\hline \multicolumn{2}{|c|}{ NISKA TECHNIKA - III kategoria } \\
\hline 15 & Produkcja artykułów spożywczych i napojów \\
\hline 16 & Produkcja wyrobów tytoniowych \\
\hline 17 & Włókiennictwo \\
\hline 18 & Produkcja odzieży i wyrobów futrzarskich \\
\hline 19 & Produkcja skór wyprawionych i wyrobów ze skór wprawionych \\
\hline 20 & Produkcja drewna i wyrobów z drewna \\
\hline 21 & Produkcja masy celulozowej, papieru oraz wyrobów z papieru \\
\hline 22 & Działalność wydawnicza; poligrafia i reprodukcja zapisanych nośników informacji \\
\hline 36 & Produkcja mebli; działalność produkcyjna, gdzie indziej niesklasyfikowana \\
\hline 37 & Zagospodarowanie odpadów \\
\hline
\end{tabular}

Źródło: Hatzichronoglou 1997 (za Nauka i technika... 2004, s. 171)

Tab. 2. Klasyfikacja działalności usługowej stosowana do analizy pracujących według poziomów „intensywności B+R” (knowledge intensity)

\begin{tabular}{|c|l|}
$\begin{array}{c}\text { Symbol działu } \\
\text { w PKD }\end{array}$ & \multicolumn{1}{|c|}{ Nazwa działu według PKD } \\
\hline \multicolumn{2}{|c|}{ USŁUGI HIGH-TECH - I kategoria } \\
\hline 64 & \multicolumn{1}{|c|}{ Poczta i telekomunikacja } \\
\hline 72 & Informatyka \\
\hline 73 & Działalność badawczo-rozwojowa \\
\hline & \multicolumn{1}{|c|}{ POZOSTALE USLUGI OPARTE NA WIEDZY - II kategoria } \\
\hline 61 & Transport wodny \\
\hline 62 & Transport lotniczy \\
\hline 65 & $\begin{array}{l}\text { Pośrednictwo finansowe, z wyłączeniem ubezpieczeń i funduszy emerytalno- } \\
\text {-rentowych }\end{array}$ \\
\hline 66 & $\begin{array}{l}\text { Ubezpieczenia oraz fundusze emerytalno-rentowe, bez gwarantowanej prawnie } \\
\text { opieki społecznej }\end{array}$ \\
\hline 67 & Działalność pomocnicza związana z pośrednictwem finansowym i ubezpieczeniami \\
\hline 70 & Obsługa nieruchomości \\
\hline 71 & $\begin{array}{l}\text { Wynajem maszyn i urządzeń bez obsługi oraz wypożyczanie artykułów użytku } \\
\text { osobistego i domowego }\end{array}$ \\
\hline 74 & Działalność gospodarcza pozostała \\
\hline 80 & Edukacja \\
\hline
\end{tabular}




\begin{tabular}{|l|l|}
\hline 85 & Ochrona zdrowia i pomoc społeczna \\
\hline 92 & Działalność związana z kulturą, rekreacją i sportem \\
\hline \multicolumn{2}{|c|}{ POZOSTALE USLUGI (less knowledge-intensive services - LKIS) - III kategoria } \\
\hline 50 & $\begin{array}{l}\text { Sprzedaż, obsługa i naprawa pojazdów samochodowych i motocykli; sprzedaż } \\
\text { detaliczna paliw do pojazdów samochodowych }\end{array}$ \\
\hline 51 & $\begin{array}{l}\text { Handel hurtowy i komisowy, z wyłączeniem handlu pojazdami samochodowymi, } \\
\text { motocyklami }\end{array}$ \\
\hline 52 & $\begin{array}{l}\text { Handel detaliczny, z wyłączeniem sprzedaży pojazdów samochodowych, } \\
\text { motocykli; Naprawa artykułów użytku osobistego i domowego }\end{array}$ \\
\hline 55 & Hotele i restauracje \\
\hline 60 & Transport lądowy, transport rurociagowy \\
\hline 63 & Działalność wspomagająca transport; działalność związana z turystyką \\
\hline 75 & $\begin{array}{l}\text { Administracja publiczna i obrona narodowa; obowiązkowe ubezpieczenia } \\
\text { społeczne i powszechne ubezpieczenia zdrowotne }\end{array}$ \\
\hline 90 & $\begin{array}{l}\text { Odprowadzanie i oczyszczanie ścieków, gospodarowanie odpadami, pozostałe } \\
\text { usługi sanitarne i pokrewne }\end{array}$ \\
\hline 91 & Działalność organizacji członkowskich, gdzie indziej niesklasyfikowana \\
\hline 93 & Działalność usługowa pozostała \\
\hline 95 & Gospodarstw domowe zatrudniające pracowników \\
\hline 99 & Organizacje i zespoły eksterytorialne \\
\hline
\end{tabular}

Źródło: opracowanie własne na podstawie Nauka i technika...2004, s. 171.

\section{SEKTOR PRZEMYSŁU I USŁUG WEDŁUG POZIOMÓW TECHNIKI - ANALIZA EMPIRYCZNA}

W sektorze przemysłowym oraz usługowym w badanych okresach dominowały jednostki niskiej techniki (kategorii III) (ryc. 1). W obrębie działalności przemysłowej w $1998 \mathrm{r}$. udział tej kategorii był jednak niższy (około 55 \%) niż w sektorze usług (68 \%). Jednocześnie udział kategorii I w przemyśle był wyższy (prawie 8\%) niż w usługach ogółem (około 1,5\%). Relatywnie mniej korzystna struktura podmiotów sektora usług wynikała prawdopodobnie z faktu, iż w początkowym okresie transformacji największą dynamikę wzrostu sektor prywatny w odniesieniu do usług przejawiał w tych dziedzinach gospodarki, w których prowadzenie działalności wiązało się przede wszystkim z koniecznością poniesienia minimalnych nakładów finansowych oraz niewielkiego zaangażowania kapitału ludzkiego (np. handel hurtowy i detaliczny) (Raczyk 2004).

W okresie 1998-2004 nastąpiło zmniejszenie znaczenia podmiotów kategorii III oraz dokonał się wzrost liczby przede wszystkim jednostek II kategorii. Było to konsekwencją ograniczenia możliwości rozwoju ilościowego jednostek z uwagi na rosnącą konkurencję, zwłaszcza w tych segmentach rynku, które nie wymagały znacznych nakładów kapitałowych. Efektem tego procesu był obserwowany w całym kraju spadek tempa wzrostu nowych podmiotów gospodarczych od połowy lat dziewięćdziesiątych (por. Raczyk 2004). Ponadto towarzyszyło temu nasilenie zmian jakościowych, polegających na tworzeniu systemu po- 
wiązań sieciowych między podmiotami gospodarczymi, przekształceniach organizacyjnych oraz intensyfikacji wykorzystania wiedzy i technologii w procesach wytwarzania dóbr i usług. Szczególnie wyraźnie było to obserwowane w sektorze usług, przede wszystkim w kategorii II.
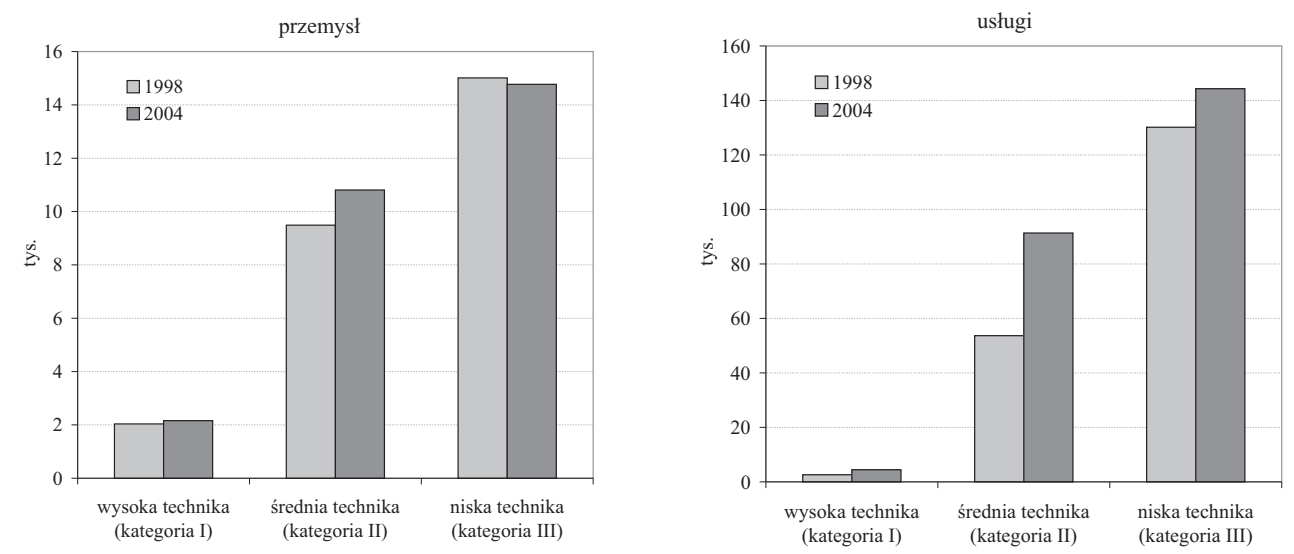

Ryc. 1. Liczba podmiotów gospodarczych według poziomów techniki w sektorze przemysłu oraz usług w gminach województwa dolnośląskiego w latach 1998, 2004

Źródło: opracowanie własne na podstawie danych z rejestru REGON, WUS

Zastanawiająca natomiast była względna stabilizacja liczby podmiotów I kategorii w obrębie działalności produkcyjnej. Dotyczyła ona w szczególności średnich i dużych podmiotów gospodarczych. Wskazuje to, iż rozwój nowoczesnej działalności gospodarczej w sektorze przemysłu napotykał na bardzo duże bariery i nie zmieniał tego w istotny sposób ani obserwowany wzrost gospodarczy, ani dynamicznie zwiększający się poziom bezpośrednich inwestycji zagranicznych w regionie w badanym okresie. Wyraźnie mniejsza dynamika przyrostu liczby podmiotów wysokiej i średniej techniki w obrębie sektora II wynikała prawdopodobnie ze jego specyfiki, w tym przede wszystkim z konieczności ponoszenia relatywnie większych nakładów inwestycyjnych (np. na park maszynowy) niż w obrębie działalności usługowej.

Jednostki kategorii III charakteryzowały się najmniejszą dynamiką wzrostu (w sektorze przemysłu nastąpił nawet spadek ich liczby). Wskazuje to na zachodzące korzystne przeobrażenia w strukturze podmiotów gospodarczych ze względu na poziom techniki w obydwu badanych sektorach.

W roku 2004 zarówno w sektorze przemysłu, jak i usług we wszystkich analizowanych kategoriach dominowały podmioty mikro, o liczbie pracujących do 9 osób (ryc. 2). Stanowiły one około $90 \% \mathrm{w}$ przemyśle i ponad $95 \% \mathrm{w}$ usługach. Zastanawiający jest natomiast fakt, iż odgrywały one największą rolę w obrębie sektora wysokiej techniki. Prawdopodobnie w odniesieniu do przemysłu było to spowodowane wcześniejszą restrukturyzacją (i w związku z tym podziałem) dużych jednostek produkcyjnych (w okresie przed rokiem 1998). W przypadku usług istotną rolę mogła odgrywać struktura działów stanowiących podstawę wydzielenia kategorii I (por. tab. 2). Dominacja podmiotów mikro mogła świadczyć również o relatywnie niewielkim popycie na usługi wysokiej techniki, a także wskazywać, iż rynek usług I kategorii znajdował się dopiero we wstępnej fazie rozwoju. 

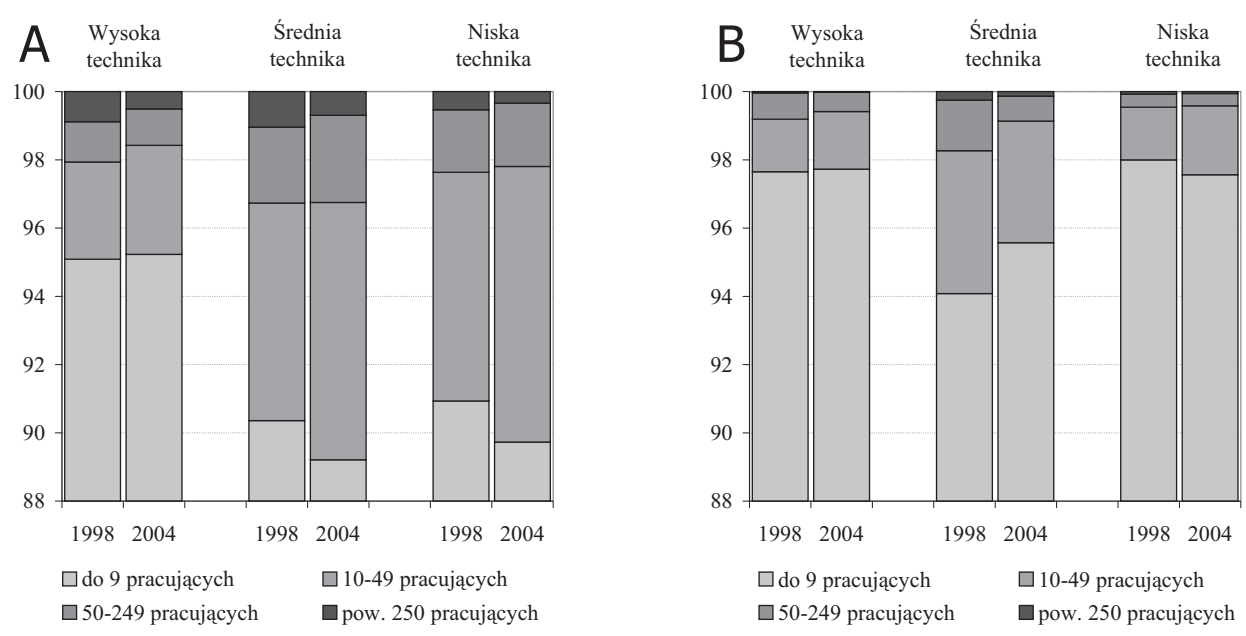

Ryc. 2. Udział podmiotów gospodarczych według poziomów techniki oraz liczby pracujących w sektorze przemysłu (A) oraz usług (B) w gminach województwa dolnośląskiego w 2004 r.

Źródło: opracowanie własne na podstawie danych z rejestru REGON, GUS

W świetle powyższej analizy można postawić hipotezę, iż przeobrażenia technologiczne w obrębie gospodarki w okresie transformacji systemowej przebiegały w trzech zasadniczych fazach:

- dynamicznego rozwoju podmiotów gospodarczych sektora przemysłu i usług, w tym przede wszystkim zaliczanych do niskiej techniki (handel hurtowy, detaliczny, produkcja artykułów spożywczych itp.) - początkowy okres transformacji,

- stabilizacji w odniesieniu do III kategorii i dynamicznego wzrostu kategorii II (usługi tzw. otoczenia biznesu, produkcja maszyn itp.), przy relatywnie znacznym udziale podmiotów średnich i dużych w strukturze przedsiębiorstw - okres nasilenia procesów restrukturyzacji,

- przewidywanego wysokiego wzrostu liczby jednostek I kategorii.

Zgodnie z powyższym podziałem gminy Dolnego Śląska w badanym okresie wykazywały cechy typowe dla fazy drugiej.

Biorąc pod uwagę strukturę działową obu sektorów, to wśród działalności produkcyjnej dominującą rolę odgrywała produkcja instrumentów medycznych, precyzyjnych i optycznych oraz zegarów i zegarków (dział 33), a także produkcja sprzętu i urządzeń radiowych, telewizyjnych i telekomunikacyjnych (dział 32), co mogło świadczyć o pewnej specjalizacji regionu w zakresie produkcji sprzętu high-tech (ryc. 3). Natomiast w aktywności usługowej zaznaczyła się dominacja działalności informatycznej (dział 72), co mogło stanowić konsekwencję rozproszonego charakteru placówek usługowych świadczących tego rodzaju usługi oraz dynamicznego rozwoju rynku usług informatycznych w ciagu ostatnich kilku lat. Należy przy tym podkreślić, iż rozwój usług informatycznych (dział 72) jest związany przede wszystkim z wykorzystaniem kapitału ludzkiego i nie wymaga ponoszenia znacznych nakładów finansowych przy uruchamianiu działalności (brak oddziaływania bariery kapitałowej). 

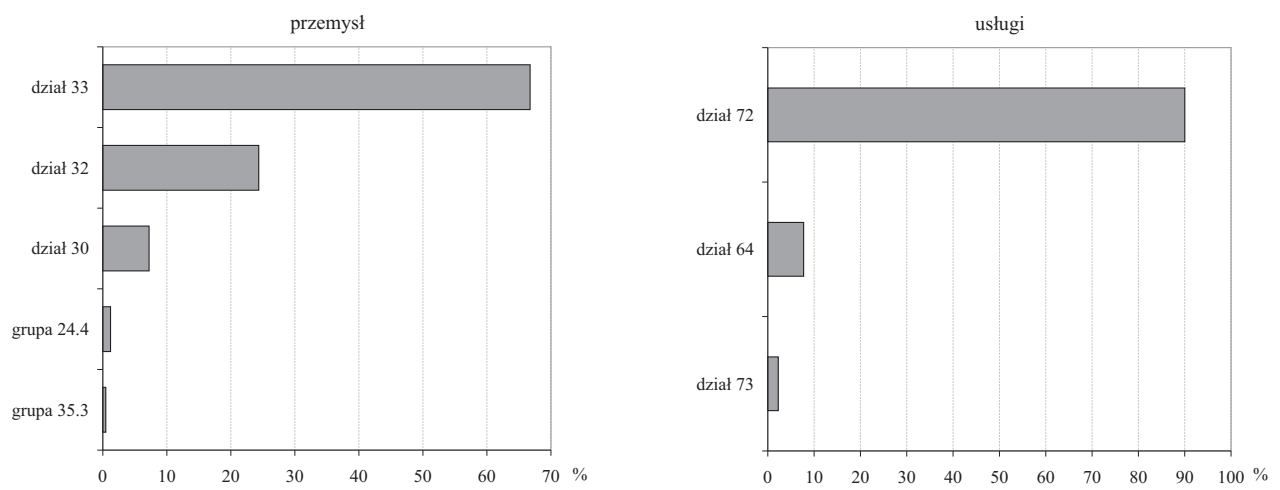

Ryc. 3. Działy i grupy PKD tworzące sektor przemysłu wysokiej techniki oraz usług high-tech na Dolnym Śląsku w 2004 roku (\%)

Źródło: opracowanie własne na podstawie danych REGON

W 2004 roku wysoka wartość wskaźnika przedsiębiorczości przemysłu I kategorii obserwowana była w dużych miastach o relatywnie nowoczesnej strukturze produkcji (Wrocław, Legnica) (ryc. 4). Ponadto występowała na obszarach o wieloletnich tradycjach w zakresie wytwarzania określonych, zaawansowanych technologicznie produktów i dysponujących kadrą specjalistów (np. Świdnica, Dzierżoniów, Bielawa). Towarzyszyła temu z reguły specjalizacja tych obszarów w zakresie wybranych dziedzin przemysłu (np. produkcja sprzętu urządzeń radiowych i telewizyjnych).
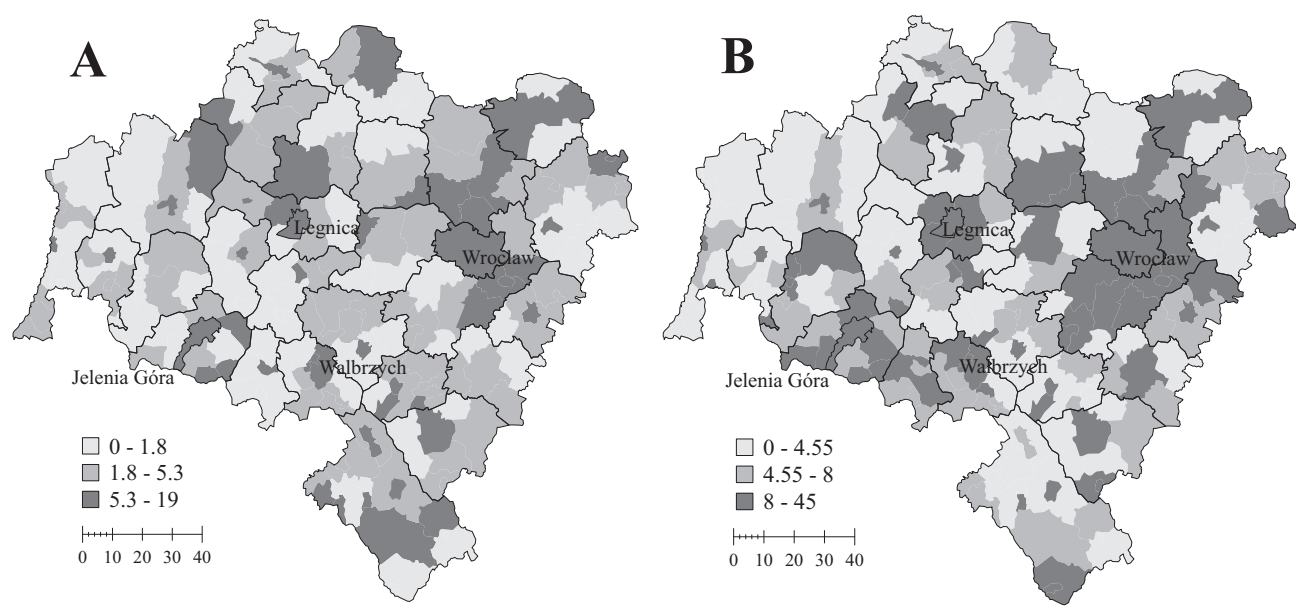

Ryc. 4. Wskaźnik przedsiębiorczości przemysłowej A) oraz usługowej (B) wysokiej techniki w gminach Dolnego Śląska w 2004 r.

Źródło: opracowanie własne na podstawie danych z rejestru REGON, WUS 
Cechą charakterystyczną zmian wskaźnika przedsiębiorczości przemysłowej wysokiej techniki w latach 1998-2004 była jego stabilizacja lub nawet niewielki spadek w największych ośrodkach miejskich (np. Legnica, Wrocław). Istotny wzrost odnotowały natomiast gminy, na terenie których zlokalizowane były podstrefy Wałbrzyskiej Strefy Ekonomicznej oraz Strefy Kamiennogórskiej (np. Dzierżoniów, Kłodzko, Świdnica, Brzeg Dolny, Kamienna Góra). Wskazuje to, iż lokalizacja strefy ekonomicznej może stanowić ważny czynnik rozwoju podmiotów przemysłu I kategorii.

W odniesieniu do sektora usług high-tech w 2004 roku największy poziom przedsiębiorczości nawiązywał do hierarchii ośrodków usługowych (Wrocław, Jelenia Góra, Legnica) (por. Jakubowicz 1991, 2000; Sokołowski 2006). Było to konsekwencją faktu, iż zasadniczą rolę w kreowaniu nowych jednostek usługowych I kategorii odgrywają czynniki poziomu rozwoju kapitału ludzkiego oraz wielkość popytu na usługi świadczone przez te podmioty.

Zmiana rozkładu przestrzennego usług wysokiej techniki sugeruje, iż istotnym czynnikiem determinującym rozwój tego sektora są powiązania funkcjonalno-przestrzenne z najważniejszymi ośrodkami miejskimi regionu (ryc. 4). Szczególnie jest to widoczne w otoczeniu Wrocławia. Miejsce danego miasta w hierarchii ośrodków usługowych nie przekreśla więc możliwości rozwoju usług I kategorii w odniesieniu do małych i średnich miast oraz gmin wiejskich.

Zmiany obserwowane w latach 1998-2004 powodują upodabnianie się struktur przestrzennych przemysłu i usług I kategorii. Potwierdza to wysoka wartość współczynnika korelacji pomiędzy przedsiębiorczością przemysłu i usług wysokiej techniki $(+0,604)$. W dłuższej perspektywie może to powodować dalszy wzrost dysproporcji przestrzennych, ponieważ obszary o relatywnie wysokich wartościach obu wskaźników będą charakteryzowały się bardziej dynamicznym wzrostem liczby podmiotów zaliczanych do wysokiej techniki. W najbardziej niekorzystnej sytuacji znajdują się zatem tereny o niskim poziomie rozwoju obu analizowanych kategorii.

\section{UWARUNKOWANIA KSZTAŁTOWANIA NOWOCZESNEJ STRUKTURY GOSPODARCZEJ}

Przeprowadzone badania wskazuja, że powstawanie podmiotów przemysłu wysokiej techniki jest związane z poziomem rozwoju sektora usług ogółem (tab. 3). Wielkość tej współzależności wzrasta i jest najwyższa w obrębie kategorii I (usługi high-tech oraz przemysł wysokiej techniki). Wzrasta również w czasie (0,600 w 2004 r.). Należy przy tym zauważyć, iż rozwój przemysłu wysokiej techniki w latach 1998-2004 praktycznie nie wpływał na sektor usług high-tech $(0,033)$. Jednocześnie jednak zmiana wskaźnika przedsiębiorczości usługowej była silnie związana z poziomem rozwoju przemysłu $(0,415)$ i usług wysokiej techniki $(0,790)$. Warunkiem powstawania nowoczesnych podmiotów gospodarczych był więc przede wszystkim rozwój nowoczesnych usług kategorii I. Może to wskazywać, iż w procesie wzrostu poziomu technologicznego gospodarki inicjującą rolę odgrywa w znacznie większym stopniu sektor usług niż sektor przemysłu. Należy wszakże pamiętać, iż szereg zależności pomiędzy oboma sektorami ma charakter sprzężeń zwrotnych, dlatego też relacje te powinny być rozpatrywane indywidualnie w odniesieniu do poszczególnych jednostek. 
Tab. 3. Współczynniki korelacji (istotne statystycznie) wskaźnika przedsiębiorczości przemysłowej i usługowej kategorii I z wybranymi wskaźnikami społeczno-ekonomicznymi w gminach województwa dolnośląskiego w latach 1998, 2004

\begin{tabular}{|l|c|c|c|}
\hline \multicolumn{1}{|c|}{ Wyszczególnienie } & Rok & $\begin{array}{c}\text { Przedsiębiorczość } \\
\text { przemysłowa } \\
\text { wysoka technika }\end{array}$ & $\begin{array}{c}\text { Przedsiębiorczość } \\
\text { usługowa wysoka } \\
\text { technika }\end{array}$ \\
\hline $\begin{array}{l}\text { Przedsiębiorczość przemysłowa } \\
\text { wysoka technika }\end{array}$ & 1998 & 1 & 0,584 \\
\hline $\begin{array}{l}\text { Przedsiębiorczość usługowa wysoka } \\
\text { technika }\end{array}$ & 2004 & 0,600 & 1 \\
\hline $\begin{array}{l}\text { Zmiana wskaźnika przedsiębiorczości } \\
\text { przemysłowej wysokiej techniki }\end{array}$ & $1998-2004$ & 0,411 & 0,033 \\
\hline $\begin{array}{l}\text { Zmiana wskaźnika przedsiębiorczości } \\
\text { usługowej wysokiej techniki }\end{array}$ & $1998-2004$ & 0,415 & 0,790 \\
\hline \multirow{2}{*}{$\begin{array}{l}\text { Udział ludności danego miasta } \\
\text { w ludności ogółem (wielkość miasta) }\end{array}$} & 1998 & 0,462 & 0,566 \\
\hline \multirow{2}{*}{ Przedsiębiorczość indywidualna } & 1998 & 0,425 & 0,523 \\
\cline { 2 - 4 } & 2004 & 0,549 & 0,613 \\
\hline \multirow{2}{*}{$\begin{array}{l}\text { Udział instytucji otoczenia biznesu } \\
\text { w ogólnej liczbie podmiotów } \\
\text { gospodarczych }\end{array}$} & 1998 & 0,642 & 0,672 \\
\hline \multirow{2}{*}{$\begin{array}{l}\text { Udział ludności z wykształceniem } \\
\text { wyższym* }\end{array}$} & 2004 & 0,585 & 0,490 \\
\cline { 2 - 4 } & 2004 & 0,735 & 0,430 \\
\hline
\end{tabular}

* dane dla $2002 \mathrm{r}$.

Źródło: opracowanie własne na podstawie danych z rejestru REGON, WUS

Jednym z najważniejszych czynników warunkujących rozwój sektora przemysłu i usług wysokiej techniki był ponadto kapitał ludzki, mierzony wskaźnikiem udziału ludności z wykształceniem wyższym (por. tab. 3). Podkreślić należy, iż jego rola w badanym okresie wyraźnie wzrosła. Wielkość ośrodka miejskiego wpływa na powstawanie nowych podmiotów obu sektorów należących do I kategorii, nie stanowi jednak czynnika najważniejszego. Interesująca jest natomiast relatywnie niewielka współzależność występowania jednostek wysokiej techniki (usług i przemysłu) z przedsiębiorczością zagraniczną (spółki z udziałem kapitału zagranicznego na 10 tys. mieszkańców w wieku produkcyjnym).Wskazuje to, iż duża liczba tych podmiotów nie zawsze przekłada się na nowoczesność gospodarki.

Wartość wskaźnika przedsiębiorczości przemysłowej oraz usługowej I kategorii związana jest z ogólnym poziomem rozwoju przedsiębiorczości indywidualnej (por. tab. 3). Wydaje się więc, że najistotniejszym czynnikiem warunkującym powstawanie nowych podmiotów gospodarczych w obrębie grupy jednostek przemysłowych i usługowych wysokiej techniki jest sprzyjanie rozwojowi przedsiębiorczości w ogóle. Działania ukierunkowane tylko na rozwój sektora przemysłu wysokiej techniki postulowane w szeregu dokumentach strategicznych formułowanych przez samorządy regionalne i lokalne mogą w tym kontekście okazać się mało skuteczne. 
Podsumowanie

Przedstawiona analiza wskazuje na występowanie wielu charakterystycznych cech kształtowania się zróżnicowań przestrzennych liczby i struktury podmiotów gospodarczych sektora przemysłu i usług według poziomów techniki na poziomie lokalnym. Do najważniejszych można zaliczyć:

- mniej korzystną ze względu na poziom techniki strukturę sektora usług w porównaniu do sektora przemysłu,

- wyraźny wzrost znaczenia podmiotów średniej i wysokiej techniki (przede wszystkim w usługach) w badanych okresie (lata 1998-2004),

- malejącą dynamikę wzrostu liczby podmiotów niskiej techniki,

- najwyższy udział podmiotów gospodarczych mikro (do 9 pracujących) i małych (do 49 pracujących) w grupie jednostek wysokiej techniki, a relatywnie mniejszy w grupie jednostek średniej i niskiej techniki,

- malejące znaczenie wielkości poszczególnych jednostek terytorialnych oraz ich miejsca w hierarchii ośrodków usługowych w kreowaniu podmiotów sektora usług high-tech, jednocześnie obserwowany wzrost znaczenia powiązań funkcjonalno-przestrzennych tych jednostek z najważniejszymi aglomeracjami miejskimi,

- relatywnie duże znaczenie lokalizacji specjalnych stref ekonomicznych w powstawaniu podmiotów sektora przemysłu wysokiej techniki,

- upodabnianie się struktur przestrzennych przemysłu i usług wysokiej techniki,

- istotny związek poziomu rozwoju przemysłu i usług wysokiej techniki z rozwojem usług ogółem oraz wskaźnikami przedsiębiorczości.

Badanie wykazało wyraźnie, iż najważniejszym czynnikiem sprzyjającym kreowaniu podmiotów gospodarczych wysokiej techniki w obrębie całej gospodarki jest kapitał ludzki. Przedstawione wnioski sugerują również, iż utrzymanie wysokiego tempa wzrostu gospodarek lokalnych może być dokonane tylko w wypadku korzystnych przeobrażeń ich struktur (zwłaszcza pod kątem poziomu rozwoju technologicznego). Tym samym kwestia zaawansowania technologicznego staje się ważnym problemem rozwoju nie tylko wybranych obszarów kraju (np. obszarów metropolitalnych, terenów Specjalnych Stref Ekonomicznych itd.), ale wszystkich lokalnych układów terytorialnych. Stanowi bowiem jeden z najważniejszych czynników determinujących kierunki i tempo procesu wewnątrzregionalnej konwergencji (dywergencji).

Jakkolwiek analiza dotyczyła przestrzeni województwa dolnośląskiego, można przypuszczać, iż obserwowane prawidłowości w kształtowaniu się przestrzennych struktur przemysłu i usług według poziomów techniki miały miejsce w skali całego kraju. W związku z wejściem Polski w struktury Unii Europejskiej i wynikającej z niego zwiększonej presji konkurencyjnej na polskie przedsiębiorstwa, przy jednoczesnych dużych nakładach finansowych na politykę strukturalną należy się spodziewać utrzymania przedstawionych trendów oraz dalszego wzrostu liczby i znaczenia podmiotów sektora wysokiej i średniej techniki. Tempo tego procesu będzie warunkowało konkurencyjność układów lokalnych i regionalnych, jak również pomyślność całego procesu integracji. 


\section{Literatura}

Chojnicki Z., Czyż T., 2006, Aspekty regionalne gospodarki opartej na wiedzy w Polsce, Bogucki, Wydawnictwo Naukowe, Poznań.

Fic M., 2004, Analiza konkurencyjności sektorów tradycyjnych i sektora high-tech w województwie lubuskim, [w:] Analiza wybranych obszarów konkurencyjności i innowacyjności w województwie lubuskim, Oficyna Wydawnicza Uniwersytetu Zielonogórskiego, Zielona Góra, s. 127-171.

Definicje pojęć z zakresu statystyki nauki i techniki, 1999, Zeszyty Metodyczne i Klasyfikacje, GUS, Warszawa.

Hatzichronoglou T., 1997, Revision of the high technology sector and product classification, STI Working Papers 1997/2, OECD, Paris.

Informacja o stanie nauki w Polsce, 2003, KBN.

Jakubowicz E, 1991, Hierarchia miejskich ośrodków ustugowych w regionie dolnoślaskim, CUP, Biuro Planowania Regionalnego we Wrocławiu, nr 7, Wrocław.

Jakubowicz E., 2000, Rola ustug ,nowych” w przeksztatceniach systemu miast regionu dolnoślqskiego, [w:] Słodczyk J. red., Społeczne, gospodarcze i przestrzenne przeobrażenia miast, Uniwersytet Opolski, Opole, s. 177-185.

Janasz W., 2005, Zmiany aktywności innowacyjnej Polski w okresie transformacji, [w:] Janasz W. red., Innowacje $w$ działalności przedsiębiorstw w integracji z Uniq Europejska, Centrum Doradztwa i Informacji Difin, Warszawa, s. 233-274.

Karpiński A., 1998, Spór o przyszłość przemystu światowego, Komitet Prognoz „Polska w XXI wieku” przy Prezydium PAN, Warszawa, s. 38-39.

Kozioł K., 2004, Identyfikacja przedsiębiorstw wysokiej technologii w województwie zachodniopomorskim, [w:] Janasz W. red., Innowacje w rozwoju przedsiębiorczości w procesie transformacji, Centrum Doradztwa i Informacji Difin, Warszawa, s. 196-215.

Nauka i technika w Polsce w 2003 roku, 2004, Informacje i Opracowania Statystyczne, GUS, Warszawa.

Niedzielski P., 2003, Polityka innowacyjna w transporcie, Uniwersytet Szczeciński, Rozprawy i Studia, T. 462, Szczecin.

Raczyk, A., 2004, Nisze aktywności gospodarczej na Dolnym Ślasku, Instytut Geografii i Rozwoju Regionalnego, Uniwersytet Wrocławski, praca doktorska.

Sokołowski D., 2006, Funkcje centralne $i$ hierarchia funkcjonalna miast w Polsce, Wydawnictwo UMK, Torun.

Wojnicka E., Rot P., Piekarec T., 2000, Sektor przedsiębiorstw wysokiej technologii w Polsce, Polska Regionów Nr 24, IBnGR, Gdańsk.

\section{Conditions of spatial diversity of service and industry sectors by level of technology on the example of Lower Silesia}

The purpose of this study was to examine the shaping of spatial diversity of economic entities in the industry sector, measured by technology levels, and the service sector, assessed by the intensity of research and development at the local level. The analysis also concerned factors determining the emergence of these diversities, as well as relations between the occurrence of economic entities in the production activity and the service sector. The survey was conducted in the Lower Silesia Voivodeship in 1998 and 2004.

The analysis revealed an increase in the participation of entities belonging to the high-tech service sector and high-tech industry sector. This participation was accompanied by a tendency of their spatial structures to become alike. It indicates that general conditions of emergence of companies characterized by the highest level of research and development intensity within the II and III sector of the economy are becoming alike. The development of high-tech industry companies is connected with the general 
development of services. This interrelation increases together with the intensity of research and development within sector III (high-tech services and knowledge-based services). It also increases with time. There exists a high, positive correlation between the value of the entrepreneurship index in the II and III sector and the general level of entrepreneurship. The crucial factor determining the formation of new economic entities in the group of high-tech industry companies and high-tech services is the overall rise of the entrepreneurship index.

dr Andrzej Raczyk

Uniwersytet Wrocławski

Instytut Geografii i Rozwoju Regionalnego

Zakład Zagospodarowania Przestrzennego

e-mail: andrzej.raczyk@geogr.uni.wroc.pl

dr Helena Dobrowolska-Kaniewska

Dolnośląska Agencja Współpracy Gospodarczej, Wrocław

e-mail: helena.kaniewska@dawg.pl 